\title{
Laurent Feller
}

Sur la formation des prix dans l'économie du haut Moyen Âge

Durant le haut Moyen Âge, l'échange marchand coexiste avec l'échange non marchand. Le but de cet article est d'examiner la présence de ces deux grandes modalités de l'échange au sein de la vie économique durant une période où l'existence même de surplus fait question. Les déficiences supposées des moyens de production, leur éventuelle inadéquation avec le développement, l'incompétence - elle aussi postulée - des élites font que l'échange par le marché et la possibilité qu'il existe un secteur de profit sont le plus souvent sous-évalués, voire niés. Les élites sociales tout comme les agriculteurs ou les commerçants ont à l'égard de la production, de la consommation et de l'échange des attitudes très nuancées et complexes. Les moines savent, au $\mathrm{Vl}^{\mathrm{e}}$ siècle, comment se forment les prix et comment il faut jouer avec les règles pour assurer son salut, tout comme au $\mathrm{IX}^{\mathrm{e}}$ siècle et la comparaison entre les pratiques d'Adalhard de Corbie et la règle de saint Benoît (ou celle du maître) livre l'explication de leur attitude à l'égard des prix: pour eux, les choses ont une valeur qu'il est possible de mesurer et de modifier. L'attitude des élites carolingiennes et post-carolingiennes lors des famines permet d'établir comment les autorités ont compris les règles de l'échange marchand à l'intérieur d'un monde chrétien. Il y a, au bout du compte, un savoir partagé mais tacite sur le fonctionnement des échanges et une conscience de ce que, en fonction des buts poursuivis, ceux-ci peuvent prendre plusieurs formes.

On price formation in the early medieval economy

During the Early Middle Ages, market exchange coexists alongside non market exchange. The aim of this paper is to examine how these two great modalities of exchange could be present at the same time in economic life, as the existence of marketeable surplus is itself doubtful. The presumed deficiencies of the means of production, their presumed unsuitability for economic development, the postulated incompetence of the elites, all combine to undervalue, even deny that a profit sector might be possible. Yet social elites as well as farmers or shopkeepers had sophisticated attitudes towards production, consumption and exchange. Sixth-century monks knew how prices were formed, and how to tinker with rules to ensure one's salvation. This knowledge also existed, within a very different framework, in the ninth century, and the comparison between the practice of such men as Adalhard of Corbie and saint Benedict, give an explanation of attitudes toward prices: for them, things had a value that could be measured and even modified. The attitude of the Carolingian and post-Carolingian elites during famines allowes us to understand how social and political authorities understood market exchange rules within a Christian society. There was a shared but tacit knowledge about exchange and a clear awareness that they could take several forms. 


\section{Monique Bourin, Sandro Carocci, François Menant, Lluís To Figueras}

Les campagnes de la Méditerranée occidentale autour de 1300 : tensions destructrices, tensions novatrices

Cet article présente une synthèse des résultats obtenus par une étude internationale menée pendant quatre années sur la conjoncture des années 1300 dans le monde de la Méditerranée occidentale chrétienne. Il en ressort une image fortement diversifiée. Géographiquement diversifiée : coexistent des régions «émergentes » en plein développement et d'autres dont les ressorts semblent usés. Et socialement diversifiée : les nouveaux chemins de l'économie et de la politique bouleversent les équilibres traditionnels, mettent à mal les anciennes formes de richesse et créent de nouvelles stratégies gagnantes. À la différence de l'Europe du Nord, l'Europe méridionale n'a pas connu la grande famine de 1315. Il n'y a pas, au Sud, de disette généralisée sauf en 1347. Les disettes y sont dues aux distorsions du marché plus qu'à la chute de la productivité des terres cultivées. L'urbanisation y est en pleine puissance et pèse sur les circuits d'approvisionnement. Le commerce pénètre partout et dans tous les milieux, notamment à partir d'un réseau de petites villes qui s'est densifié au cours du XIII siècle. Rien n’indique un réel manque de monnaie : le crédit, omniprésent, y supplée mais contribue à redistribuer les cartes économiques et sociales.

The countryside in the Western Mediterranean around 1300:

destructive tensions, and innovative tensions

This article summarizes the results of an international research study conducted over four years into the situation in the Western Mediterranean Christian world circa 1300. A highly diversified image emerges. It is a geographically diversified one with some areas in full development coexisting with others that seem worn out, and a socially diversified one with new economic and political pathways completely changing traditional balances, undermining the old forms of wealth and creating new winning strategies. Unlike the north of Europe, southern Europe did not experience the great famine of the year 1315. There was no generalized dearth of food in the South, with the exception of the year 1347. The shortages there were due to market distortions more than to a fall in productivity of the cultivated land. The urbanization process was in full force and relied heavily on supply networks. Trade reached everywhere and in all environments, thanks especially to a network of small towns that became denser during the $13^{\text {th }}$ century. There was no indication of a real lack of currency: ubiquitous credit filled in for it and encouraged a redistribution of the economic and social cards.

\section{Giuliano Milani}

Avidité et trahison du bien commun dans une peinture infamante mantouane du XIII ${ }^{\mathrm{e}}$ siècle

Sur la base d'une nouvelle lecture d'une inscription conservée au Palazzo della Ragione de Mantoue, l'article propose de réinterpréter la peinture au sein de laquelle cette inscription est insérée comme l'un des premiers témoignages de peinture infamante parvenus jusqu'à nous, réalisée pour punir les citoyens qui avaient remis aux ennemis le château communal de Marcaria en 1251. La présence du motif iconographique de la bourse autour du cou conduit à réfléchir à la définition des comportements contraires à la bonne gestion des ressources publiques dans les communes italiennes du Moyen Âge et, plus largement, à l'usage des images pour véhiculer des messages idéologiques. 
Greed and betrayal of the public good in a $13^{\text {th }}$-century Mantuan defamatory painting

Starting from an inscription held at the Palawso della Ragione in Mantua, this article reinterprets a painting where this inscription was inserted as one of the first instances of a defamatory painting, made to punish those citizens who had turned the municipal castle of Marcaria in 1251 over to their enemies. The iconographic motif of the purse hanging from the neck is an invitation to think about how attitudes contrary to the good management of public resources was defined in Italian cities in the Middle Ages, and more largely how images were used to convey ideological messages.

\section{Thomas Dodman}

Un pays pour la colonie

Mourir de nostalgie en Algérie française, 1830-1880

Bien avant l'époque de la «nostalgérie », les ambitions coloniales de la France en Algérie se heurtaient déjà à une "nostalgie africaine ». Comme le découvrirent les premiers soldats et colons qui traversèrent la Méditerranée en 1830, cette nostalgie du sol natal était une maladie dangereuse, un mal du pays aux conséquences souvent fatales. Or, à peine quelques décennies plus tard, il ne restait plus de cette pathologie que le nom: diagnostic devenu désuet, la nostalgie laissa la place à une forme bénigne «d'amour du pays » qui, par un retournement original, offrait désormais aux Français d'Algérie la possibilité de se ressourcer dans un cadre de vie familier - dans un pays implanté dans la colonie. Cet article retrace la trajectoire surprenante de cette maladie dont la disparition fut l'occasion paradoxale de relancer une colonisation jusque là chancelante, et de donner corps à l'idée d'une «Algérie française».

\section{A pays for the colony: Deadly nostalgia in French Algeria, 1830-1880}

Long before the days of "nostalgérie", French colonial ambitions in Algeria already came up against a "nostalgie africaine". As the first French soldiers and settlers discovered when they crossed the Mediterranean in 1830, this particular form of nostalgia was then a dangerous and often fatal disease. And yet, barely a few decades later, this deadly form of homesickness had all but disappeared. In its place, the French now cultivated an entirely benign form of nostalgia that provided them with a much-needed sense of homeliness in Algeria - a pays implanted in the colony. This article follows the surprising trajectory of a disease that somehow managed, in its twilight, to revive the fortunes of a staggering colonization bid, thus giving substance to the idea of a "French Algeria".

\section{Olga Koveneva}

Vivre ensemble dans la nature et dans la ville

Capacités et expériences de la mise en commun en France et en Russie

L'article présente un regard comparatif sur les modalités d'agrandissement de la cause environnementale en France et en Russie depuis des usages locaux. En suivant de près la formation progressive des collectifs écologiques, nous mettons en lumière les exigences qui pèsent sur la transformation de l'environnement de proximité, mais aussi sur celle des personnes en êtres publics. Nous appréhendons les tensions qui accompagnent ce mouvement, les vacillements et basculements entre les attachements locaux et engagements publics, ainsi que les tentatives politiques de laisser place, voire de mettre en valeur 
au sein-même du format public, les relations personnelles et attaches familières. Cette démarche nous permet de porter un regard symétrique et nuancé sur les cas étudiés et de rendre compte des difficultés et obstacles qui jalonnent le chemin de l'apprentissage de l'exercice démocratique.

Living together in nature and in the city: Capacities and experiences of making common cause in France and in Russia

The article presents two scenarios of development of the environmental cause in France and Russia. Starting with familiar environmental uses and personal engagements in the immediate environment, we follow the formation of environmentalist groups with public status. The essay analyzes local evolutions from personal attachment to public commitment, and efforts to gather appropriate equipment and devices for such apprenticeship. We pay attention to the switching back and forth between personal links and public commitment, as well as to political attempts to make room for personal environmental uses. This approach, based on a subtle symmetrical analysis of the cases under study, aims to produce an account of the plurality of human engagements in their dynamics and at clarifying difficulties and tensions these experiences imply. 